\title{
Growth rates and persistence of annual and perennial clovers
}

\author{
Sonya T. OLYKAN ${ }^{1 *}$, Richard J. LUCAS ${ }^{1}$, Stuart R. HUNTER ${ }^{1}$ and Derrick J. MOOT ${ }^{1}$ \\ ${ }^{1}$ Dryland Pastures Research, Field Research Centre, Faculty of Agriculture and Life Sciences, PO Box 85084, \\ Lincoln University, Lincoln 7647, New Zealand \\ *Corresponding author: sonya.olykan@lincoln.ac.nz
}

\begin{abstract}
The temporal productivity of monocultures of four annual and two perennial clover species was quantified in a summer dry environment at Lincoln University, Canterbury. In 2019, cultivar affected $(\mathrm{P}<0.001)$ yield in early spring with 'Viper' balansa producing $5.0 \mathrm{t}$ $\mathrm{DM} /$ ha compared $(\mathrm{P}<0.05)$ with $3.5 \mathrm{t}$ for 'Arrotas' arrowleaf, $3.2 \mathrm{t}$ for 'Antas' and 'Woogenellup' sub clovers, $1.6 \mathrm{t}$ for 'Kopu II' white clover and $1.2 \mathrm{t}$ for 'Relish' red clover. After a dry autumn in 2020, white and red clovers regrew, but only 'Napier' and 'Woogenellup' sub clovers re-established from seed. By September 2020, 'Woogenellup' sub (4.3) and 'Relish' red (3.7) clovers had higher dry matter (t/ha) yields than 'Kopu II' white (2.8) and 'Napier' sub (2.2). In contrast, autumn 2020 re-establishment of arrowleaf, balansa and Persian clovers was poor, and each yielded $<0.5 \mathrm{t} \mathrm{DM} / \mathrm{ha}$ by September and were dominated by weeds. These results confirm poor re-establishment of these top flowering clovers in their second year, and recommendations for their use as specialist oneyear crops. The earlier growth profiles of the annual compared with perennial clovers highlighted their potential to increase early spring feed supply to meet requirements of sheep in dry regions.
\end{abstract}

Keywords: Balansa, top flowering, winter yield

\section{Introduction}

In dryland systems, plants that produce high quality feed in spring, when soil moisture is non-limiting, enable maximum animal production in lactating stock and their offspring (Macfarlane et al. 2014). Animal live weight gain averages $40 \%$ more with clover than ryegrass, due to more efficient utilisation of metabolisable energy (ME) for growth (Nicol and Edwards 2011). In addition, pastures with high legume content in early spring have higher water-use efficiency, (Moot 2012) due to their ability to fix $\sim 30 \mathrm{~kg}$ $\mathrm{N} / \mathrm{t}$ of clover dry matter (Lucas et al. 2010). In contrast, grass dominant pastures are frequently $\mathrm{N}$ deficient at this time, which restricts growth and reduces water efficiency (Mills et al. 2006). Perennial legumes can be productive in dryland environments. Peak white clover growth rates of $50 \mathrm{~kg} \mathrm{DM} / \mathrm{ha} / \mathrm{d}$ have been measured in mid-October (Black et al. 2003). Similarly, red clover (T. pratence) in a dryland monoculture accumulated $\sim 16 \mathrm{t} \mathrm{DM} / \mathrm{ha} / \mathrm{yr}$ in the first two years, with growth rates peaking in mid-November at $\sim 70 \mathrm{~kg} \mathrm{DM} / \mathrm{ha} / \mathrm{d}$ (Brown et al. 2003). However these perennial red and white clovers are suited to environments with $>750 \mathrm{~mm}$ annual rainfall with at least $150 \mathrm{~mm}$ in summer (Brock et al. 2003). Low soil moisture in summer decreases the rate of taproot carbohydrate replenishment in red clover, which slows regrowth and stands frequently only persist for 2 to 3 years (Brock et al. 2003). White clover plants are vulnerable to summer dry conditions after 1 to 2 years, because their taproot dies and they become small stoloniferous clonal plants (Brock and Hay 2001) with shallow root systems. In contrast, winter active annual legumes can accumulate high quality biomass over the winter and early spring period (Hyslop et al. 2003) and can be more productive during late winter and spring (Evans and Mills 2008; Teixeira et al. 2017).

Long-term persistence and resilience are important considerations for annual clovers, because they need to re-establish viable plant populations from a seed bank. Therefore first year seed set and level of hardseededness, are important considerations. Macfarlane et al. (2015) reported that grazing the top-flowering arrowleaf ( $T$. vesiculosum) and Persian (T. resupinatum) clovers after mid to late October greatly reduced their seed set. However, allowing them to set seed means the paddock is closed at peak animal demand and results in a large amount of lignified and unpalatable above-ground dry matter. In contrast, to maximise first year subterraneum (sub) clover (T. subterranean) seed set, Olykan et al. (2019) recommended a six week cessation from grazing, followed by light cattle grazing to produce a seed bank. This allowed clover to be controlled through grazing management (Monks et al. 2008; Olykan et al. 2019) and the level of hardseededness (Teixeira et al. 2021).

In New Zealand, with its cool climate, sub clovers (Lucas et al. 2015; Olykan et al. 2018) and balansa (T. michelianum) (Monks et al. 2008) with low ratings of hardseededness are most successful in re-establishing populations from the seed bank. In contrast, reestablishment can be poor for Persian, even though it is soft-seeded (Macfarlane et al. 2015; Nori et al. 2019), and for arrowleaf, which has a high level of hardseededness (Nori et al. 2019).

This study compared growth rates of monocultures of annual and perennial clovers at Lincoln, Canterbury over two years. 


\section{Methodology and analysis}

An experiment was established in March 2019 at Lincoln University, Canterbury, New Zealand (GPS coordinates $-43.6493,172.4659$, elevation $10 \mathrm{~m}$ a.s.1.). The site is $\sim 21 \mathrm{~m}$ (west-east) by $100 \mathrm{~m}$ long (northsouth) and located in a flat paddock in Iversen Field 4. The soil is Wakanui silty loam (NZ: Mottled Immature Pallic Soils, USDA: Aeric Epiaquept) that is $>100 \mathrm{~cm}$ deep and imperfectly drained (Manaaki Whenua 2021). Bulk soil samples ( 20 cores from the $0-75 \mathrm{~mm}$ depth) were taken on 22 February 2019 and 17 June 2020 and analysed by Hill Laboratories Ltd. Results indicated adequate soil fertility in both years (Table 1).

\section{Site preparation}

After a summer fallow in 2019, the area was conventionally cultivated and rolled. A pre-sowing spray of Weedmaster 540 (540 g glyphosate/L) at $2 \mathrm{l} /$ ha in 2001 water was applied on 20 March 2019 to kill emerging weeds. A germination test used two replicates of 50 seeds of each cultivar, incubated for seven days at $18^{\circ} \mathrm{C}$ to determine sowing rates. Five replicates of 10 clovers were direct drilled on 22 March 2019, using a Flexiseeder ${ }^{\circledR}$ drill into $10 \times 4.2 \mathrm{~m}$ plots in a randomised, split-block design, with the blocks split by growth habit (Table 2). The site was heavy rolled post-sowing.

Post-emergence, on the 10 May 2019, the area was sprayed with Preside (800 g flumetsulam $/ \mathrm{kg}$ ) at a low rate of $30 \mathrm{~g} / \mathrm{ha}$ in 2001 of water to target spurrey (Spergula arvensis). On 13 May 2019, clover plant population density was visually scored using a scale from 1 (poor) to 10 (excellent). The area was sprayed on 27 June 2019 with $330 \mathrm{ml} /$ ha Centurion Xtra (360 g clethodim /1) with 21 uptake oil/ha in 2001 water to target the Poa grass (Роа апnиа). For Year 1, herbage was harvested on 14 August, 28 August (three replicates), 24 September, 9 October, 19 November, 19 December 2019 and 7 January 2020 (four replicates). A change in sampling occurred because Replicates 1 and 2 were slow to establish. However, they recovered and Replicate 5 was subsequently dropped due to poor growth. 'Napier' and 'Lusa' Persian did not establish adequate populations for harvest. 'Cefalu' arrowleaf showed visual symptoms of herbicide damage, so was

Table 1 Soil chemical analyses of bulk samples (0-75 mm depth) from Iversen Field 4W, Lincoln University, Canterbury, taken on 22 February 2019 and 17 June 2020. MAF Quick Test units are shown in brackets for the cations.

\begin{tabular}{lcc|ccc|c}
\hline Date & pH & $\begin{array}{c}\text { Olsen P } \\
(\mathbf{m g} / \mathbf{L})\end{array}$ & Potassium & $\begin{array}{c}\text { Calcium } \\
(\mathbf{m e} / \mathbf{1 0 0} \mathbf{g})\end{array}$ & $\begin{array}{c}\text { Magnesium } \\
\text { (mg/kg) }\end{array}$ \\
\hline Feb-19 & 6.3 & 21 & $1.2(27)$ & $8(11)$ & $1.1(26)$ & 11 \\
Jun-20 & 6.0 & 16 & $0.8(17)$ & $7(8)$ & $1.0(21)$ & 7 \\
\hline
\end{tabular}

Table 2 Agronomic and experimental details for the clover species and cultivars sown at Lincoln University, Canterbury in March 2019.

\begin{tabular}{llccc}
\hline Clover species & Cultivar & Growth habit $^{3}$ & TSW (g) & Sowing rate kg/ha $^{\mathbf{4}}$ \\
\hline Arrowleaf & Arrotas & Tall & 1.55 & 20 \\
& Cefalu & Tall & 1.83 & 10 \\
\hline Balansa & Taipan C & Tall & 0.97 & 20 \\
& Viper & Tall & 1.15 & 10 \\
\hline Persian & Lusa & Tall & 1.06 & 10 \\
\hline Subterranean & Antas (B) & & 20 \\
& Napier C (Y) & Short & 7.81 & 40 \\
\hline Red & Woogenellup (S) & Short & 12.2 & 20 \\
\hline White & Relish C & Short & Short & 1.96 \\
\hline
\end{tabular}

${ }^{1} \mathrm{C}$ - sown as coated seed;

2 Subterranean subspecies: $\mathrm{B}=$ brachycalycinum, $\mathrm{S}=$ subterraneum, $\mathrm{Y}=$ yanninicum;

${ }^{3}$ Growth habit $=$ tall (erect top flowering stems or long scrambling stems), short (prostrate);

4 TSW: Thousand Seed Weight of bare seed. Coated TSW: 'Taipan' $1.70 \mathrm{~g}$, 'Napier' $25.0 \mathrm{~g}$, and 'Relish' $4.80 \mathrm{~g}$;

${ }^{5}$ Coated seed sown at double the rate of bare seed. 


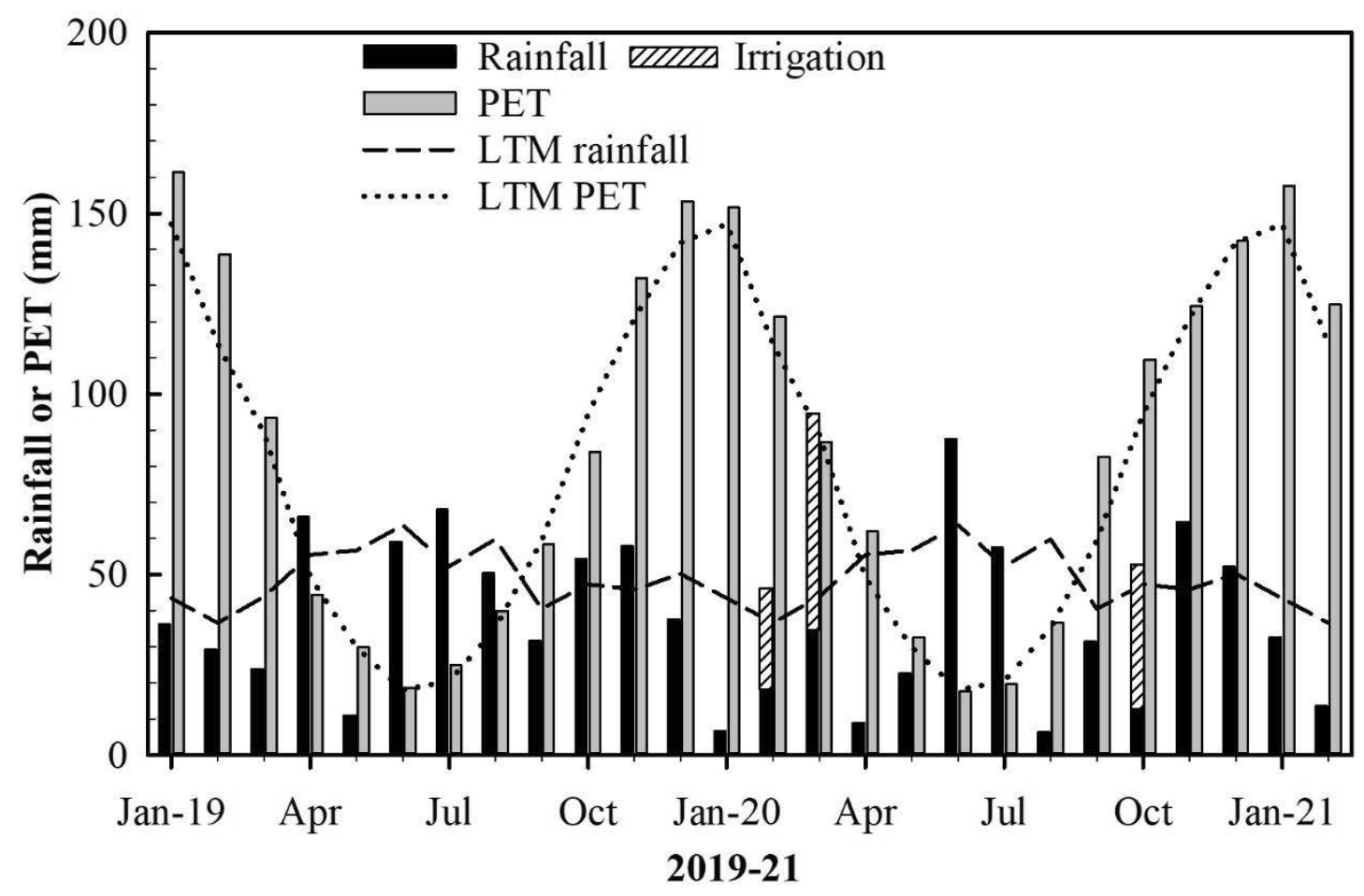

Figure 1 Total monthly rainfall, evapotranspiration (PET) and irrigation from January 2019 to February 2021 at Lincoln (Canterbury). Data, including 30 year (1990-2019) long term mean (LTM), from Lincoln-Broadfield station (CliFlo 2020).

not sampled until 7 January 2020.

From 20 to 23 January 2020 the site was grazed by 140 dry ewes and residual stems removed by mowing to a height of $60 \mathrm{~mm}$ on 4 February. This left bare ground with minimal litter or herbage cover. Year 2 started with below average rainfall (Figure 1), so irrigation was applied with $28 \mathrm{~mm}$ on 25-27 February $2020,30 \mathrm{~mm}$ on 9-10 March and a final $30 \mathrm{~mm}$ on 18 March 2020, in anticipation of the Covid-19 lockdown on 25 March 2020. Annual clover emergence was not observed due to the Covid-19 lockdown, but estimated to be $\sim 20$ March, two days after the third irrigation event. On 14 October 2020, $40 \mathrm{~mm}$ irrigation was applied because the was $42 \mathrm{~mm}$ rainfall since 1 August 2020 was well below the long term mean (Figure 1). On 19 October 2020, $80 \mathrm{~kg}$ /ha superphosphate (P 9, S 11, Ca 20) and $180 \mathrm{~kg} / \mathrm{ha}$ sulphur super 30 (P 7, S 30, Ca 16) were applied.

Germination tests of the seeds set in Year 1, were carried out in July 2020 on seed from fully mature plants of 'Taipan' (harvested 29 November 2019) and 'Viper' balansa (17 December 2019), and 'Arrotas' (28 January 2020) and 'Cefalu' (14 January 2020) arrowleaf that had been air dried and stored in paper bags. Seeds were taken from the dried flower heads. Seeds of 'Antas' sub clover were taken from burrs collected on site.

In 2020 (Year 2), harvests occurred when there was sufficient ( 2 to $3 \mathrm{t} \mathrm{DM} / \mathrm{ha}$ ) clover herbage that farmers would utilise if on-farm. This occurred on 26 May (white, red, and 'Woogenellup' sub), 20 August (white, red, 'Woogenellup' and 'Napier' subs, Persian); 17 September, 2 November and 9 December 2020 (all clovers). On 26 January 2021 only red clover and white clover were sampled. After each harvest, the site was grazed for 1 to 2 days by 145 mixed-age dry ewes and then mown to $30 \mathrm{~mm}$ with the residual herbage removed. Exceptions were after 20 August harvest, site was ungrazed or mown because the plants were small, and after 17 September harvest only the red, white and 'Napier' and 'Woogenellup' sub clover plots were mown, as the other annual clover plants were too small.

Herbage mass was cut using motorised shears to a stubble height of $20 \mathrm{~mm}$ from one $0.2 \mathrm{~m}^{2}$ quadrat/ plot to indicate productive potential. Samples were separated into clover, weed and dead components, dried at $65^{\circ} \mathrm{C}$ for 48 hours, and weighed. On 26 January and 5 March 2021, visual groundcover assessments were made of the red and white clover plots.

Near-infrared (NIR) spectroscopy (FOSS NIRSystems 5000) of the clover component of the 2020 harvests determined metabolisable energy (ME) and crude protein. Accumulated thermal time was calculated from 1 July 2019 using a two-stage model. To enable comparisons among species (Moot et al. 
2000) a common set of cardinal temperatures was used with a base of $0^{\circ} \mathrm{C}$, optimum of $26^{\circ} \mathrm{C}$ and maximum of $37^{\circ} \mathrm{C}$. In 2020 thermal time was accumulated from the day after mowing.

\section{Climate}

Climate data were from the Lincoln-Broadfield meteorological station located $2.6 \mathrm{~km}$ north of the site (CliFlo 2020). Annual mean maximum and minimum air temperatures were 17.7 and $7.4^{\circ} \mathrm{C}$ in 2019 , respectively, and 17.6 and $7.3^{\circ} \mathrm{C}$ in 2020 . Both years were warmer than the 30-year long-term mean (LTM, 1990-2019) of 16.7 and $6.6^{\circ} \mathrm{C}$. Annual rainfall (January to December) was $525 \mathrm{~mm}$ in 2019 and $403 \mathrm{~mm}$ in 2020. In 2019, germination started in early April after $30 \mathrm{~mm}$ rain. May had only $11 \mathrm{~mm}$ of rain (Figure 1) but winter/spring monthly rainfall was close to the LTM. In 2020, January and February were drier than average (7 and $18 \mathrm{~mm}$ ) as were April and May (9 and $23 \mathrm{~mm}$ ). After a total of $145 \mathrm{~mm}$ rainfall in June/July, there was only $6 \mathrm{~mm}$ in August and $12 \mathrm{~mm}$ in October.

In 2019 and 2020 the annual PET was 980 and 990 $\mathrm{mm}$, respectively, which indicated a maximum potential soil moisture deficit of $587 \mathrm{~mm}$ in 2020 .

\section{Statistical analyses}

Genstat statistical software (18th edition) was used for all statistical analyses.

In 2019, clover growth rates were calculated from individual plot data, except for the 24 September to 9 October period, when the means were used due to the change in replicates sampled. In 2020, all growth rates were calculated using the individual plot data. Clover yield, accumulated yield, total DM, growth rates at each harvest, ME and protein values were analysed by oneway ANOVA with growth habit (Table 2) as a covariate and clover cultivar as the factor. The orthogonal contrasts were annual versus perennial (2019 only), sub clover versus perennial or top flowering annuals, and top flowering annuals versus perennial. Cultivar means separation used LSD $\alpha=0.05$. The relationship between accumulated DM and thermal time was analysed using least squares linear regression with groups based on clover cultivar and then clover groupings using cultivars when slopes were not different. In 2019, the clover groupings were 1) 'Taipan' and 'Viper' balansa, 2) 'Antas' and Woogenellup' subs and 'Arrotas' arrowleaf, and 3) perennials 'Relish' red and 'Kopu II' white. In 2020, groups were 1) 'Napier' and 'Woogenellup' subs with 'Relish' red and 'Kopu II' white, and 2) the remaining annuals.

\section{Results}

\section{Germination tests}

Pre-sowing germination was $>90 \%$ for all seeds compared with the Year 1 (2020) field results at 3 and $8 \%$ for 'Arrotas' and 'Cefalu' arrowleaf seeds, 29 and $25 \%$ for 'Taipan' and 'Viper' balansa and $8 \%$ for 'Antas' sub.

\section{Establishment - Year 1 (2019)}

Clover cultivar affected $(\mathrm{P}<0.001)$ seedling population scores on 13 May 2019. 'Arrotas' arrowleaf was 9.4 \pm 0.31 , higher $(\mathrm{P}<0.05)$ than 'Cefalu' (7.4), 'Taipan' and 'Viper' balansa (7.0). 'Antas' and 'Woogenellup' sub and perennial clovers scored 4.0 and 'Lusa' Persian (0.6) and 'Napier' (1.2) sub scores were the lowest $(\mathrm{P}<0.05)$.

\section{Accumulated clover dry matter yield - 2019}

In Year 1 'Arrotas' arrowleaf accumulated yield peaked at $12,900 \mathrm{~kg} \mathrm{DM} / \mathrm{ha}$ on 19 December 2019, which was higher $(\mathrm{P}<0.05)$ than 'Woogenellup' sub $(10,000 \mathrm{~kg}$ $\mathrm{DM} / \mathrm{ha})$, 'Relish' red (7,950 kg DM/ha), and 'Antas' sub $(7,670 \mathrm{~kg} \mathrm{DM} / \mathrm{ha})$ clovers, which were higher than 'Kopu II' white $(4,600)$ clover (Figure 2). The accumulated clover DM yields at each harvest were affected $(\mathrm{P}<0.001)$ by cultivar. From 28 August until 9 October the annual clovers had higher $(\mathrm{P}<0.05) \mathrm{DM}$ yields than the perennial clovers (Figure 2).

In late winter and early spring, the balansa cultivars 'Taipan' and 'Viper' produced $\sim 1500 \mathrm{~kg} \mathrm{DM} / \mathrm{ha}$, and 'Antas' and 'Woogenellup' sub clovers had $~ 800 \mathrm{~kg}$ $\mathrm{DM} /$ ha by the 14 August (Figure 2). Six weeks later, on the 24 September, 'Viper' had accumulated 5,010 $\mathrm{kg} \mathrm{DM} / \mathrm{ha}$, which was not different from 'Taipan' $(3,890 \mathrm{~kg} \mathrm{DM} / \mathrm{ha})$ but higher $(\mathrm{P}<0.05)$ than 'Antas' and 'Woogenellup' sub clovers $(\sim 3,200 \mathrm{~kg} \mathrm{DM} / \mathrm{ha})$ and the 'Arrotas' arrowleaf (3,500 kg DM/ha). By 28 August 2019, the accumulated yields of the perennial 'Kopu II' white and 'Relish' red clovers were $~ 230$ $\mathrm{kg} \mathrm{DM} / \mathrm{ha}$ and less $(\mathrm{P}<0.05)$ than the annuals. By the 19 November, the $6,300 \mathrm{~kg} \mathrm{DM} / \mathrm{ha}$ from 'Relish' was not different from the highest annual clover yields and higher $(\mathrm{P}<0.05)$ than 'Kopu II' (4140 kg DM/ha). Year 1 sown clover as a percent of the total DM differed $(\mathrm{P}<0.05)$, increased from $61 \%$ and $48 \%$ for annuals and perennials, respectively, on 14 August to $96 \%$ and $88 \%$ by 19 November.

Accumulated clover dry matter yield - Year 2 (2020) Yield in Year 2 was accumulated from 4 February for the perennials and 20 March for the annuals. On 26 May, 'Kopu II' white, 'Relish' red and 'Woogenellup' sub yields of $\sim 1,400 \mathrm{~kg} \mathrm{DM} / \mathrm{ha}$ (Figure 2) were not different. There was insufficient herbage to sample the other clovers. By 20 August, 'Relish' had a higher $(\mathrm{P}<0.05)$ accumulated yield $(2,890 \mathrm{~kg} / \mathrm{ha})$ than 'Napier' $(1,340 \mathrm{~kg} / \mathrm{ha})$ while 'Woogenellup' and 'Kopu II' accumulated 2,340 and 2,010 kg DM/ha, respectively. 


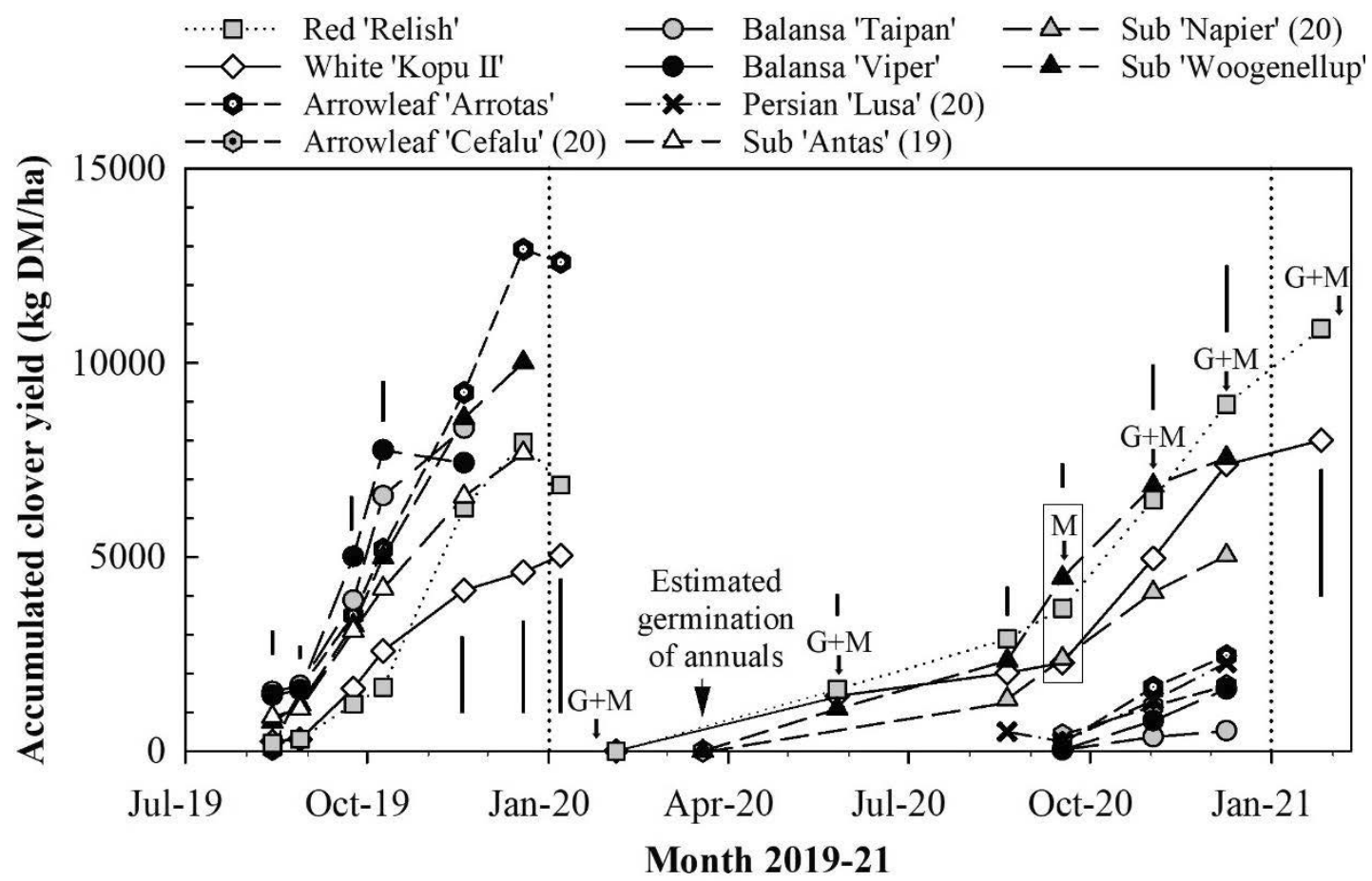

Figure 2 Accumulated clover dry matter yield of non-grazed (2019-20) and grazed (2020-21) monocultures of annual and perennial clovers grown at Lincoln University, Canterbury. If a clover was not sampled in both years, the year of sampling was noted. 1 January = dotted vertical line ( $\vdots)$. In 2020, $\downarrow=$ grazing (G) and/or mowing (M) after harvest. Bars at each harvest are LSD $5 \%$.

'Woogenellup' and 'Relish' had the highest $(\mathrm{P}<0.05)$ accumulated yields of 4,460 and $3,680 \mathrm{~kg} / \mathrm{ha}$ by 17 September, and both accumulated $\sim 6,700 \mathrm{~kg} /$ ha by 2 November.

After the December harvest, the sub clover cultivars senesced, while red and white clovers continued to grow. By 26 January 2021, 'Relish' had accumulated $10,900 \mathrm{~kg} \mathrm{DM} / \mathrm{ha}$ and the $1,950 \mathrm{~kg} / \mathrm{ha}$ grown since 19 December 2020 was higher $(\mathrm{P}<0.05)$ than the $630 \mathrm{~kg} /$ ha from 'Kopu II'.

In Year 2, the first harvest of 'Lusa' Persian on 20 August only yielded $500 \mathrm{~kg} \mathrm{DM} /$ ha which was lower $(\mathrm{P}<0.05)$ than the other clovers. The arrowleaf and balansa cultivars were first harvested on 17 September and their clover yield, with 'Lusa', averaged $190 \mathrm{~kg}$ $\mathrm{DM} / \mathrm{ha}$ (range of 34 to $420 \mathrm{~kg}$ ), or $12 \%$ of the total DM harvested.

\section{Daily growth rates - Year 1 (2019)}

In Year 1, daily clover growth rates from August to November differed $(\mathrm{P}<0.05)$ among cultivars. 'Arrotas' grew $111 \mathrm{~kg} \mathrm{DM} / \mathrm{ha} / \mathrm{d}$ from 14 to 28 August, which was higher $(\mathrm{P}<0.05)$ than the other clovers (Figure $3 \mathrm{~A})$. From the 28 August, 'Viper' and 'Taipan' balansa grew 123 and $106 \mathrm{~kg} \mathrm{DM} / \mathrm{ha} / \mathrm{d}$, respectively, and had the highest growth rates $(\sim 180 \mathrm{~kg} \mathrm{DM} / \mathrm{ha} / \mathrm{d})$ from 24 September to 9 October. 'Kopu II' growth rate peaked at $65 \mathrm{~kg} \mathrm{DM} / \mathrm{ha} / \mathrm{d}$ on 24 September, and 'Relish' at 113 $\mathrm{kg} \mathrm{DM} / \mathrm{d}$ on 19 November (Figure 3A). Apart from 'Arrotas', annual clover growth rates declined after 9 October, particularly for the balansa cultivars.

\section{Daily growth rates - Year 2 (2020)}

From 26 May to 20 August, the growth rate of the harvested clovers was $\sim 13 \mathrm{~kg} \mathrm{DM} / \mathrm{ha} / \mathrm{d}$ (Figure 3B). On 17 September, 'Woogenellup' sub had a growth rate of $75 \mathrm{~kg} \mathrm{DM} / \mathrm{ha} / \mathrm{d}$ which was double $(\mathrm{P}<0.05)$ that of 'Napier' sub. On 9 December 2020, the perennial clovers averaged $74 \mathrm{~kg} \mathrm{DM} / \mathrm{ha} / \mathrm{d}$, which was higher $(\mathrm{P}<0.05)$ than the $21 \mathrm{~kg} \mathrm{DM} / \mathrm{ha} /$ day of the annuals (Figure 3B).

\section{Accumulated DM yield versus accumulated thermal time}

To enable species comparisons, growth rates were calculated per unit of temperature accumulated per day $\left({ }^{\circ} \mathrm{Cd}\right.$ ) (Mills et al. 2006; Mills et al. 2021). From 14 August to 9 October 2019, balansa clovers grew $11 \mathrm{~kg}$ $\mathrm{DM} / \mathrm{ha} /{ }^{\circ} \mathrm{Cd}$, sub and arrowleaf clovers $8 \mathrm{~kg} \mathrm{DM} / \mathrm{ha} /{ }^{\circ} \mathrm{Cd}$ and red and white at $4.0 \mathrm{~kg} \mathrm{DM} / \mathrm{ha} /{ }^{\circ} \mathrm{Cd}$ (Figure $4 \mathrm{~A}$ ). In 


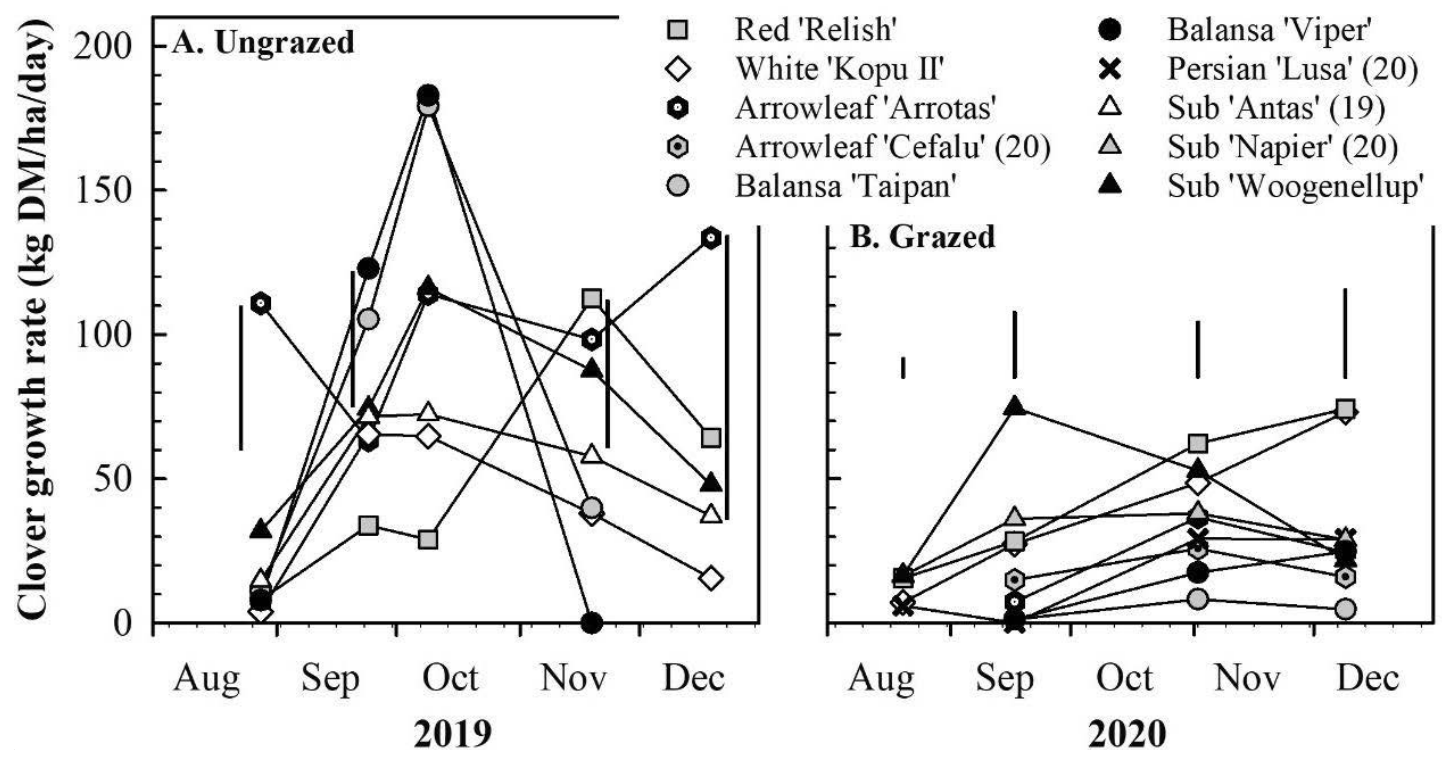

Figure 3 Annual and perennial clover cultivar monoculture growth rates of A. 2019 non-grazed and B. 2020 grazed from August to December at Lincoln University, Canterbury. If clover was not sampled both years, year of sampling (19 or 20) noted. Bars are LSDa5\% for each harvest, except for 9 October 2019, when growth rates calculated from mean DM values

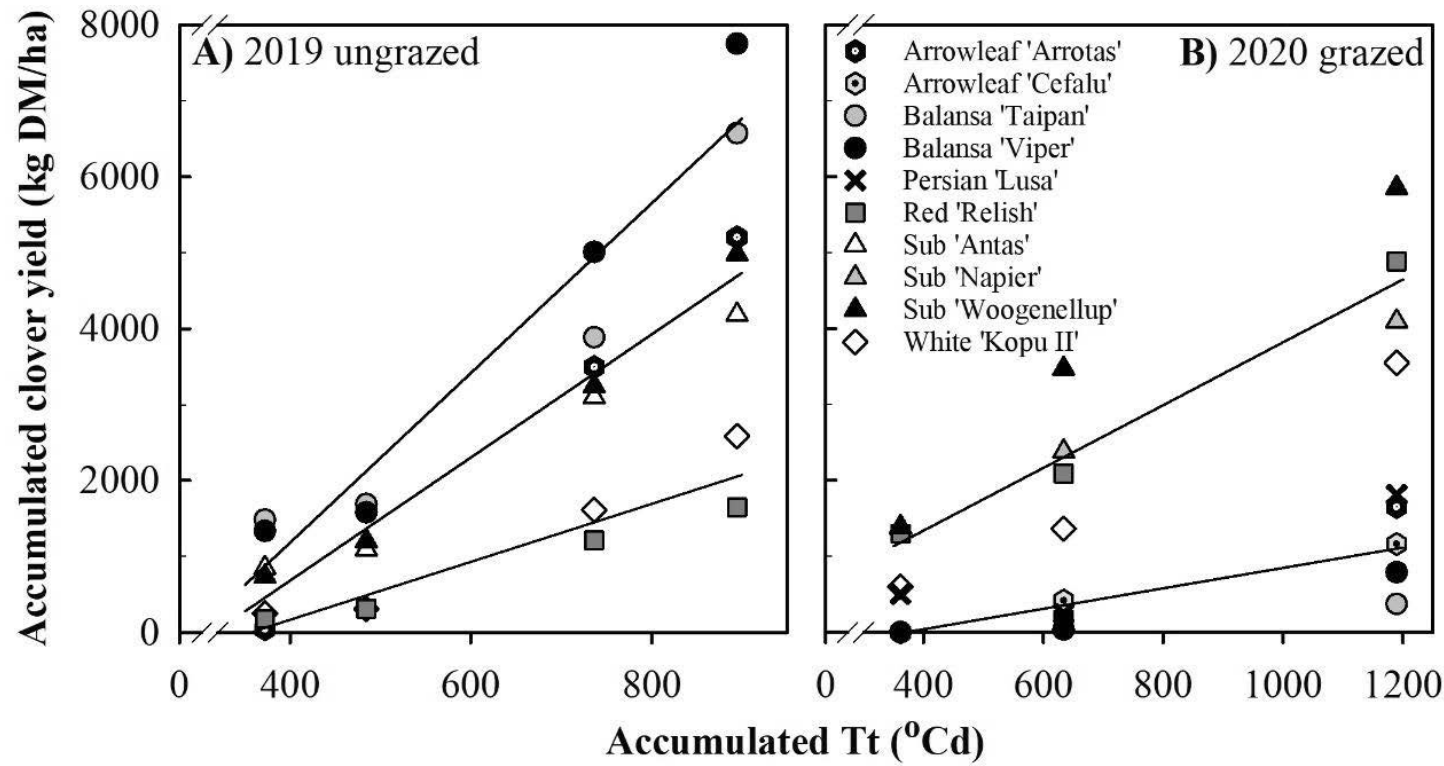

Figure 4 Accumulated dry matter (DM) against accumulated thermal time (Tt) for clover monocultures harvested from A) 2019 non-grazed plots (14 August to 9 October), groupings were 1) balansas, 2) arrowleaf + sub clovers, 3) perennial red + white clovers, and B) 2020 grazed plots (20 August to 2 November) groupings 1) sub + red + white clovers, 2) other annuals (balansas + arrowleafs + Persian), at Lincoln University, Canterbury. $\left(\mathrm{Tb}=0^{\circ}\right)$.

2020, from 20 August to 2 November, 'Woogenellup' sub clover grew $5.2 \mathrm{~kg} \mathrm{DM} / \mathrm{ha} /{ }^{\circ} \mathrm{Cd}$, which was not different to 'Relish' red $\left(4.4 \mathrm{~kg} \mathrm{DM} / \mathrm{ha} /{ }^{\circ} \mathrm{Cd}\right)$, but higher $(\mathrm{P}<0.05)$ than 'Kopu II' white and 'Napier' sub clover at 3.6 and $3.2 \mathrm{~kg} \mathrm{DM} / \mathrm{ha} /{ }^{\circ} \mathrm{Cd}$ respectively. These clovers grouped together had a higher $(\mathrm{P}<0.05)$ mean growth rate of $4.1 \mathrm{~kg} \mathrm{DM} / \mathrm{ha} /{ }^{\circ} \mathrm{Cd}$ compared with the top flowering annual clovers at $1.3 \mathrm{~kg} \mathrm{DM} / \mathrm{ha} /{ }^{\circ} \mathrm{Cd}$ (Figure 4B; $\mathrm{R}^{2}=87.2$ ).

\section{Feed quality}

In 2020, clover herbage ME values peaked on 17 September and ranged from 11.0 in 'Relish' red to 12.5 $\mathrm{MJ} / \mathrm{kg}$ DM in 'Kopu II' white clover. Protein peaked 
at $33.3 \%$ for 'Kopu II' in August, and then declined. 'Woogenellup' sub clover had the highest accumulated total ME and protein on 17 September due to its higher $(\mathrm{P}<0.05)$ herbage production.

\section{Groundcover assessment 2021}

'Relish' red and 'Kopu II' white clover groundcover declined during the dry summer in 2021 from 70 and $36 \%$, respectively on 26 January, to 27 and $6 \%$ by 5 March.

\section{Discussion}

\section{Establishment Year 1 - 2019}

The annual arrowleaf, balansa and sub clovers established high plant populations. Given the aim was to optimise winter production of annual clovers in dryland systems, early sowing of seed can be recommended (Moot et al. 2003a) to take advantage of any late summer rainfall. Weed competition occurred during the autumn, requiring herbicide to support establishment. The success of this strategy was apparent in midNovember, when sown clover represented $95 \%$ of the total DM. However, 'Cefalu' arrowleaf appeared to be more sensitive to herbicide, so additional work for this species is needed.

In Year 1, the annual clovers were all more productive than white clover, which supports previous reports (Evans and Mills 2008; Teixeira et al. 2017) and was most apparent in the critical spring period of August to October.

The accumulated yield profiles of the top flowering balansa and arrowleaf clovers matched feed requirements of ewes and lambs in dryland areas. Mean lambing date was $\sim 20$ August at Lincoln, so high quality pastures are required in early August. 'Arrotas' arrowleaf grew the fastest in August (111 kg DM/ha/d) while 'Viper' balansa grew at $123 \mathrm{~kg} / \mathrm{ha} / \mathrm{d}$ during September and then at $183 \mathrm{~kg} \mathrm{DM} / \mathrm{ha} / \mathrm{d}$ into early October. However, these impressive growth rates resulted from stands left to seed. Allowing full seed set meant the two top flowering species were unavailable for grazing and feed quality declined (Hackney et al. 2021) before it could be used. The consequent residual herbage was difficult to 'clean-up' over summer (Macfarlane et al. 2015). In practice, sub clover provided opportunity for both grazing and seed set in the establishment year. For topflowering clovers, an early spring graze may be possible but can compromise the level of seed set. However, given the lack of re-emergence for some cultivars in Year 2, farmers may opt to use this early season feed and resow each year. Neither of the perennial legumes produced useful amounts of feed in early spring from a mid-autumn sowing.

In Year 1, the annual clovers, particularly the balansa cultivars, grew more DM per unit of thermal time than the perennial clovers, highlighting their superior late winter-early spring growth. Sub clovers grew at twice the rate of the perennial clovers. 'Arrotas' arrowleaf continued growing into the summer and accumulated $12,900 \mathrm{~kg} \mathrm{DM} / \mathrm{ha}$, which emphasised its ability to extend the growing season when ungrazed (Evans and Mills 2008).

In Year 1 the red clover growth rates of $113 \mathrm{~kg} \mathrm{DM} /$ ha/d were the highest from early October until midNovember as the annual clovers, except arrowleaf, were in decline. Ideally perennials would have been sown in spring or late summer (Moot et al. 2000) but, in practice, the LTM rainfall suggests this is not feasible in dryland areas.

\section{Year 2 - 2020}

In Year 2 'Antas' sub clover, balansa, arrowleaf, and Persian clovers had zero to low populations of seeds reestablish so were dominated by weeds. A germination test of seed harvested in January 2020 showed that $<10 \%$ of the arrowleaf 'Arrotas' and 'Cefalu' and $<30 \%$ of the 'Taipan' and 'Viper' balansa seeds germinated. The hardseededness of arrowleaf has previously been noted as an issue in re-establishing plants in from the initial seed bank (Evans and Mills 2008; Macfarlane et al. 2015), while the Persian cultivar 'Lusa' was moderately hardseeded (Evans 2006). Production from top flowering annuals in year two and beyond was unpredictable and ongoing contribution in summer dry environments was less reliable than sub clover (Taylor et al. 2021)). These results supported the premise that arrowleaf and Persian and, to a lesser extent, balansa monocultures may be grown as one-season specialised legume feed for grazing from late winter to early summer or for forage production (Hyslop et al. 2003; Zhang et al. 2004).

'Napier' and 'Woogenellup' sub clover along with the two perennials produced sufficient feed for grazing. As expected, growth rates were lower under grazing than in the non-grazed establishment year. 'Woogenellup' growth rates were highest $(\mathrm{P}<0.05)$ from mid-August to mid-September and provided the most ME and protein/ ha in late winter/early spring. 'Relish' red clover was as productive as 'Woogenellup' from mid-September, presumably due to mobilising root reserves. 'Kopu II' white clover suffered from dry conditions more than red clover, probably due to the short-lived nature of its tap roots (Widdup and Barrett 2011). White and red clovers accumulated more DM and had the highest growth rates from November onwards, when the annual sub clover was dying.

The Year 2 yields highlighted the potential 'complementarity' of sub and perennial clovers in rainfed environments, provided there is sufficient summer rainfall for perennials to survive. In this 
experiment, red and white clover groundcover declined during summer 2021, after low rainfall of $54 \mathrm{~mm}$ from January to March. Being an annual, sub clover avoids the summer dry conditions as a hard seed and relies on the late summer autumn rains to re-establish each year. Despite growing in a deep, fertile soil, there was insufficient summer rainfall to sustain these perennials into year three.

\section{Conclusions}

These results highlighted the difficulties of dryland farming. An increasingly variable climate (Salinger 2003) means a range of strategies are required to manage legumes to provide effective high quality feed. The mass of unpalatable herbage and unreliable seed germination in Year 2 from top flowering annuals suggests an opportunity to used them as single season sources of forage in their vegetative state in earlier spring and to fix nitrogen. In contrast, sub clover is the most likely winter annual to fit dryland pastoral systems, due to earlier spring production than perennial legumes. Maintaining its seed bank is required to maximise the contribution to the farm system over time. White and red clover provided the opportunity for summer growth responses to rainfall, as seen in 2019/20, but lucerne could provide the greatest production and persistence in these environments (Moot et al. 2003b).

\section{ACKNOWLEDGEMENTS}

Lincoln University technical staff (David Jack, Dan Dash, Malcolm Smith) for pasture establishment and management, and Dr Keith Pollock (climate data). Funding was provided by Beef + Lamb New Zealand, MBIE, Seed Force New Zealand and PGG Wrightson Seeds under the "Hill Country Futures" research programme (BLNZT1701).

\section{REFERENCES}

Black AD, Moot DJ, Lucas RJ. 2003. Seasonal growth and development of Caucasian and white clovers under irrigated and dryland conditions. Presented at: Legumes for dryland pastures. Proceedings of a New Zealand Grassland Association symposium, Lincoln University. Pp. 73-79. https://doi.org/10.33584/ rps.11.2003.2992

Brock JL, Hay MJM. 2001. White clover performance in sown pastures: A biological/ecological perspective. Proceedings of the New Zealand Grassland Association 63: 73-83. https://doi.org/10.33584/ jnzg.2001.63.2434

Brock JL, Hyslop MG, Widdup KH. 2003. A review of red and white clovers in a dryland environment. Presented at: Legumes for dryland pastures. Proceedings of a New Zealand Grassland Association symposium. Lincoln University. Pp. 101-107. https:// doi.org/10.33584/rps.11.2003.3001

Brown HE, Moot DJ, Pollock KM. 2003. Long term growth rates and water extraction patterns of dryland chicory, lucerne and red clover. Presented at: Legumes for dryland pastures. Proceedings of a New Zealand Grassland Association symposium. Lincoln University. Pp. 91-99. https://doi.org/10.33584/ rps.11.2003.2991

CliFlo. 2020. NIWA's National Climate Database on the Web. Retrieved 20/01/2020 http://cliflo.niwa. co.nz.

Evans PM. 2006. Persian Clover (Trifolium resupinatum) 'Lusa'. Plant Varieties Journal 19: 4346. https://www.ipaustralia.gov.au/tools-resources/ pbr-journals

Evans PM, Mills A. 2008. Arrowleaf clover: potential for dryland farming systems in New Zealand. Proceedings of the New Zealand Grassland Association 70: 239-243. https://doi.org/10.33584/ jnzg.2008.70.2702

Hackney BF, Rodham CA, Dyce G, Plitz J. 2021. Pasture legumes differ in herbage production and quality throughout spring, impacting their potential role in fodder conservation and animal production. Grass and Forage Science 76: 116-133. https://doi. org/10.1111/gfs. 12525

Hyslop MG, Slay MWA, Moffat CA. 2003. Dry matter accumulation and sheep grazing preference of six winter active annual legumes. Presented at: Legumes for dryland pastures. Proceedings of a $\mathrm{New}$ Zealand Grassland Association symposium, Lincoln University. Pp. 117-121. https://doi.org/10.33584/ rps.11.2003.3006

Lucas RJ, Smith MC, Jarvis P, Mills A, Moot DJ. 2010. Nitrogen fixation by subterranean and white clovers in dryland cocksfoot pastures. Proceedings of the New Zealand Grassland Association 72: 141-146. https://doi.org/10.33584/jnzg.2010.72.2825

Lucas RJ, Mills A, Wright S, Black AD, Moot DJ. 2015. Selection of sub clover cultivars for New Zealand dryland pastures. Journal of New Zealand Grasslands 77: 203-210. https://doi.org/10.33584/ jnzg.2015.77.459

Macfarlane MJ, Thomson BC, Crofoot EW, Hamilton G, Ashby H, Muir PD. 2014. Evaluating new forage systems for East Coast dryland. Proceedings of the New Zealand Society of Animal Production 74: 108114. http://nzsap.org/proceedings/2014/evaluatingnew-forage-systems-east-coast-dryland

Macfarlane MJ, Crofoot EW, Muir PD. 2015. Effects of closing date on seeding and hardseededness of balansa, gland, Persian and arrowleaf clovers on East Coast dryland. Journal of New Zealand Grasslands 77: 219-226. https://doi.org/10.33584/ jnzg.2015.77.461 
Manaaki Whenua. 2021. Retrieved 06/05/2021 https:// smap.landcareresearch.co.nz.

Mills A, Moot DJ, McKenzie BA. 2006. Cocksfoot pasture production in relation to environmental variables. Proceedings of the New Zealand Grassland Association 68: 89-94. https://doi.org/10.33584/ jnzg.2006.68.2636

Mills A, Thomson BC, Muir PD, Smith NB, Moot DJ. 2021. Resident hill country pasture production in response to temperature and soil moisture over 20 years in Central Hawke's Bay. Presented at: Resilient Pastures. Hamilton. Grassland Research and Practice Series 17. Pp. 39-48. https://doi.org/10.33584/ rps.17.2021.3451

Monks DP, Moot DJ, Smith MC, Lucas RJ. 2008. Grazing management for regeneration of balansa clover in a cocksfoot pasture. Proceedings of the New Zealand Grassland Association 70: 233-238. https:// doi.org/10.33584/jnzg.2008.70.2701

Moot DJ, Scott WR, Roy AM, Nicholls AC. 2000. Base temperature and thermal time requirements for germination and emergence of temperate pasture species. New Zealand Journal of Agricultural Research 43: 15-25. https://doi.org/10.1080/002882 33.2000.9513404

Moot DJ, Black AD, Scott WR, Richardon J. 2003a. Leaf development and dry matter production of subterranean clover cultivars in relation to autumn sward management. Presented at: Legumes for dryland pastures. Proceedings of a New Zealand Grassland Association symposium. Lincoln University. Pp. 193-200. https://doi.org/10.33584/ rps.11.2003.3008

Moot DJ, Brown HE, Teixeira EI, Pollock KM. 2003b. Crop growth and development affect seasonal priorities for lucerne managment. Presented at: Legumes for dryland pastures. Proceedings of a New Zealand Grassland Association symposium. Lincoln University. Pp. 201-208. https://doi.org/10.33584/ rps.11.2003.3007

Moot DJ. 2012. An overview of dryland legume research in New Zealand. Crop and Pasture Science 63: 726-733. http://dx.doi.org/10.1071/CP12103

Nicol AM, Edwards GR. 2011. Why is clover better than ryegrass? Proceedings of the New Zealand Society of Animal Production 71: 71-78. http://www.nzsap.org/ proceedings/2011/why-clover-better-ryegrass

Nori H, Moot DJ, Mills A. 2019. Seed production, seedling regeneration and hardseeds breakdown of annual clovers. New Zealand Journal of Agricultural Research 62: 316-331. https://doi.org/10.1080/00288 233.2018.1488747

Olykan ST, Lucas RJ, Teixeira CS, Subtil RA, Moot DJ. 2018. Establishment, production and regeneration of subterranean clovers in the Mackenzie Basin, New Zealand. Journal of New Zealand Grasslands 80: 145-153. https://doi.org/10.33584/jnzg.2018.80.319

Olykan ST, Lucas RJ, Nicholson DJ, Doscher C, Moot DJ. 2019. Maximising the subterranean clover content on a summer-dry Wairarapa hill-country farm through grazing management. Journal of New Zealand Grasslands 81: 91-99. https://doi. org/10.33584/jnzg.2019.81.391

Salinger J. 2003. Climate reality - actual and expected. Presented at: Legumes for dryland pastures: proceedings of a New Zealand Grassland Association (Inc.) Symposium. Lincoln University. Pp. 13-18. https://doi.org/10.33584/rps.11.2003.2999

Taylor BJO, Mills A, Smith M, Lucas RJ, Moot DJ. 2021. Yield and botanical composition of four dryland pastures at Ashley Dene Research Farm over 8 years. Presented at: Resilient Pastures Symposium. Lake Karapiro. Grassland Research and Practice Series 17. Pp. 29-37. https://doi.org/10.33584/ rps.17.2021.3445

Teixeira C, Lucas R, Lewis T, Moot D. 2017. From establishment to re-establishment: a field evaluation of sub clover cultivars. Presented at: Proceedings of the 18th Australian Society of Agronomy Conference, 24 - 28 September 2017. Ballarat, VIC, Australia. http://agronomyaustraliaproceedings.org.

Teixeira CSP, Hampton JG, Moot DJ. 2021. Time of sowing and cultivar effects on hardseededness and germination of subterranean clover seeds. New Zealand Journal of Agricultural Research. https:// doi.org/10.1080/00288233.2020.1861030

Widdup KH, Barrett BA. 2011. Achieving persistence and productivity in white clover. Pasture Persistence - Grassland Research and Practice Series 15: 173180. https://doi.org/10.33584/rps.15.2011.3206

Zhang X, Evans PM, Riffkin RA. 2004. Performance of annual pasture legumes in cropping rotations in the cool temperate zone of south-eastern Australia. Australian Journal of Experimental Agriculture 44: 863-871. https://doi.org/10.1071/ea03093 